Journal of Southeast Asian

Volume 15

Issue 2 Voices from the Field: Centering

Southeast Asian Americans through Policy,

Article 4

Practice, and Activism

2020

\title{
Navigating Refugee Subjecthood: Cambodian American \\ Education, Identity, and Resilience
}

Yvonne Y. Kwan

San Jose State University, yvonne.y.kwan@sjsu.edu

Follow this and additional works at: https://docs.lib.purdue.edu/jsaaea

Part of the Bilingual, Multilingual, and Multicultural Education Commons

\section{Recommended Citation}

Kwan, Yvonne Y. (2020) "Navigating Refugee Subjecthood: Cambodian American Education, Identity, and Resilience," Journal of Southeast Asian American Education and Advancement. Vol. 15 : Iss. 2, Article 4. DOI: $10.7771 / 2153-8999.1208$

Available at: https://docs.lib.purdue.edu/jsaaea/vol15/iss2/4

This document has been made available through Purdue e-Pubs, a service of the Purdue University Libraries. Please contact epubs@purdue.edu for additional information.

This is an Open Access journal. This means that it uses a funding model that does not charge readers or their institutions for access. Readers may freely read, download, copy, distribute, print, search, or link to the full texts of articles. This journal is covered under the CC BY-NC-ND license. 


\section{Navigating Refugee Subjecthood: Cambodian American Education, Identity, and Resilience}

\section{Cover Page Footnote}

I want to first thank all of the participants who volunteered to share their stories and experiences with me. Your narratives are so powerful--especially in their ability to provide evidence necessary to support the much needed increase in outreach and accessibility of education to Southeast Asian Americans. Second, I want to offer a heartfelt thank you to Peter Keo, Loan Dao, Fang Gao and others at the JSAAEA team for all your hard work. 


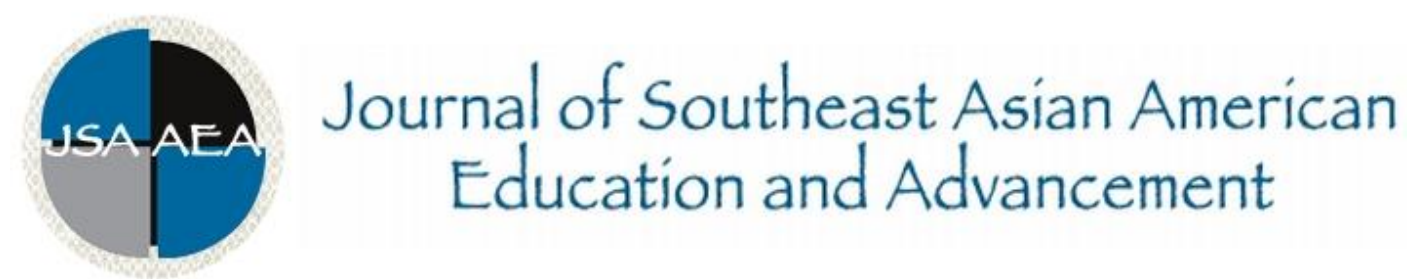

Vol. 15 Iss. 2 Special Issue (2020) www.JSAAEA.org

\title{
Navigating Refugee Subjecthood: Cambodian American Education, Identity, and Resilience
}

\author{
Yvonne Y. Kwan \\ San Jose State University
}

\begin{abstract}
To investigate trauma formation associated with the intricacy of Cambodian-specific experiences, this study examines how refugee identities and daily diasporic experiences shape the larger subject positions of subsequent generations - particularly through the concept of refugee subjecthood. Cambodia American students' navigation of ethnic and racial identity reveals that in comparison to the available discursive narratives about their history (given to them through multicultural education), the younger generations' is an inexact fit. To draw out the relationships between collective feelings and social experiences, this article addresses how Cambodian American students not only come into recognition about their positions as refugee subjects but also suggest why higher education practitioners need to provide support for and recognition of student challenges and strengths associated with refugee diaspora.
\end{abstract}

Keywords: Cambodian Americans, Transgenerational trauma, Identity

\section{Introduction}

To investigate trauma formation associated with Cambodian-specific experiences, this article examines how refugee identities and daily diasporic experiences shape refugee subjecthood. Refugee subjecthood bridges subjectivity and historical trauma across different temporalities to allow for transgenerational engagements about the conditions of living as refugee subjects, including survivors and their descendants. Cambodian American students' navigation of ethnic identity reveals that in comparison to the available discursive narratives about their history (given to them through multicultural education), the younger generations' is an inexact fit. To draw out the relationships between collective feelings and social experiences, I will address how Cambodian American students not only come into recognition about their positions as refugee subjects but also suggest why higher education practitioners need to provide support for and recognition of student challenges and strengths associated with refugee diaspora.

Scholars such as Khatharya Um (2015) have employed concepts such as refugitude to thread together French colonialism, postcolonial politics, war, exile and diaspora, and the legacies

(c)

SDIRERIGHISRESERNEDReaders are free to copy, display, and distribute this article, as long as the work is attributed to the author(s) and the Journal of Southeast Asian American Education \& Advancement, it is distributed for non-commercial purposes only, and no alteration or transformation is made in the work. More details of this Creative Commons license are available at http://creativecommons.org/licenses/by-nc-nd/3.0/. All other uses must be approved by the author(s) or JSAAEA.

Journal of Southeast Asian American Education \& Advancement, Vol. 15. Iss. 2. (2020) ISSN: 2153-8999 
of trauma and suffering to describe the forces that shape and create refugee dislocations. This text, however, foregrounds transgenerational experiences through a queer and affective theoretical lens rather than a solely historical and political one. While the definition of "refugee" is officially designated by state powers, this work and the work of other critical refugee studies scholars posit that the experiences of living in refuge transcend reductionist notions and instead point to different modes of negotiation and imagination. For example, Vinh Nguyen's (2019) concept of refugeetude also challenges the restrictive legal definition of refuge(e). He conceptualizes refugeetude as a subjectivity wherein refugee subjects come into a consciousness about the social, political, and historical forces that allow them to generate connections with the past, present, and future among multiple forms of displacement.

\section{Subjecthood and Identity}

Pushing Um and Nguyen's theorizations even further, this text offers generational nuance and space for embodied affective engagement, weaving together history, politics, militarism, and diplomacy, as well as interlocutors' personal experiences to produce an archive of trauma (Cvetkovich, 2003). As refugee subjects, this study's participants demonstrate complex and sometimes contradictory ways in which subsequent generation survivors come into recognition of their individual identities and their collective subjecthood around war and diaspora. Subjecthood, therefore, is the phenomenon in which individuals who belong to a similar cultural group create, enact, and challenge the subject positions they inhabit. Refugee subjecthood does not require discursive utterance or identity naming but instead revolves around the affects of trauma-the positive, negative, and neutral feelings, emotions, and sensations that are elicited in the daily lives of refugees (Murphy, 2019, p. 37). Subsequent generations may not "remember" the war or dislocation but they live, sense, and feel the memories and silences of their elders' pasts. Refugee subjecthood is thus inclusive of an assemblage of embodied figurations of diaspora in juxtaposition with encounters structured by race, class, gender, sexuality, and nation. It dislocates the foci of engagement from individual subjectivities to allow for transgenerational relationalities about the collective conditions of living as refugees (Bell, 2002).

Worlding practices via touching, feeling, and listening to the mundane and the ordinary interactions become portals into the imaginative, fantastical, and speculative. And, queer relationalities across generations of refugees serve to also mediate such practices. ${ }^{1}$ In this context, queer not only relates to non-normative and expansive gender and sexual desires and relations, but also alternative modes of sensing, feeling, and thinking about the world - modes that defy traditional or linear clock time and spatial limitations, so that we can not only challenge dominant notions of nationhood and citizenship but also resistant/resilient forms of living-surviving-thriving within the afterlives of diaspora and trauma.

Education, in particular, serves as an important site for students to explore their cultures, histories, and heritage. In describing successive-generation Cambodian American aspirations for pursuing higher education, there is a coalescing of filial obligations that are rooted in survivor guilt along with veneration of parent sacrifice (Kwan, 2019). For Cambodian Americans, both firsthand and transgenerational trauma experiences can be rearticulated not only as individual suffering but shared experience - especially around a conspiracy of silence in which the older generation avoids speaking about the traumas of the past (Kidron, 2010, 2011, 2012; Wajnryb, 2001). I apply Jonathan Flatley's (2008) "antidepressive melancholia" to recognize how loss (via silence) can produce a structure of feelings around refugee subjecthood-a tethering together of survivor pain 
with transgenerational worlding practices for younger generations. While silence is often pathologized as an individual's failure to narrate and subsequently cope with the traumas of the past, silence carries with it affects of trauma-allowing embodied intensities to leak from generation to generation or from one person to another - not via direct speech but instead collective and public feelings. For example, a person experiences certain feelings not because this person identifies as a refugee but instead, it is the feelings associated with growing up as a child of refugees that produces the refugee subject. Therefore, refugee subjecthood does not require overt discursive utterance or identity naming.

\section{Methods}

The findings in this chapter were drawn from 27 semi-structured interviews with secondgeneration Cambodian American college students and recent college graduates. The vast majority of participants were first-generation college students who relied on financial aid. Pseudonyms were used to protect all participant identities. Participants were selected using reputational case selection, which involves asking individuals in the community who are familiar with secondgeneration refugee experiences to recommend individuals for participation in the study (Schensul, Schensul, \& LeCompte, 1999). In addition to personal contacts, Cambodian/Khmer student organizations at various universities in California were central to granting access. The interviews, which ranged from one to two hours, helped draw out the multiple yet similar dimensions of identity formation and trauma traces. Interviews were then transcribed and analyzed thematically and visually using Atlas-ti software.

\section{Findings: Making Individual Identities and Forming a Subjecthood}

Participants in this study continue to stake claims on their Americanness while also recognizing the centrality of how war and refugee experiences shape their identities - who they are, how they feel, and what they do. Understandings about who they are and how they should act, are largely shaped by the children's recognition and understanding of parents' struggles and contributes to the formation of a larger refugee subjecthood-beyond that of individual identity. For example, it took many years for Alyssa to realize that her parents had experienced something tremendously hurtful and tragic. When she was seven years old, she and her family went on a trip to Cambodia. She remembers going to the S-21 Tuol Sleng Genocide Museum, a former high school that was transformed into a prison and torture site by the Khmer Rouge (KR). Though she was unsure why her family was there, she said that she had "a sense of what it was." This affective connection and intensity defied cognition and allowed her to have a shared embodied experience while in the presence of something so "stark and grim." Not only did her young body feel "freaked out" by the museum, but she also thought it was "surprisingly unimpressive because it was just like a dilapidated building." These contradictory affects would later intertwine and transform into deeper attachments when Alyssa began learning about the KR as she entered into adulthood. The visit generated an incipience that would later develop into and empathetic connection between Alyssa and her parents.

Now in retrospect, Alyssa shares, "Seeing my father was really powerful." By juxtaposing her father's presence and those fears she experienced at the prison, she would imagine how "that could've been him." This thought scared her, and she actively tries to push these thoughts about the death and suffering from her consciousness. But nonetheless, Alyssa is still articulated to these feelings that she had experienced as a young person. They were latent but always incipient and 
becoming. Older now, Alyssa has a "much better appreciation" of that visit because as she discusses, "I can put that into perspective and understand the uniqueness of [my parents'] situation, the uniqueness of how I am here." By developing this ability to reflect on and draw parallels between her parents' experiences, her current situation, and larger sociohistorical contexts, Alyssa can better manage her schoolwork and other demands. Alyssa shares,

It really helps when I am struggling through problem sets at school. It's like, “Oh, I hate this. I don't want to do this anymore." Then you just remind yourself, like "Well, my parents survived a genocide, so I think I can do this."

So while it is possible for transgenerational trauma to manifest as a burden or something with which children must cope, it is also possible that the affects of trauma can function as inspiration for children to persevere when they experience certain pressures. Sometimes the articulations of latent trauma may be expressed as both burden and inspiration-simultaneously and contradictorily. $^{2}$

As young adults, many participants believed that obtaining an education was one of the few ways that they could give back to their parents. In order to do so, it was very important for them to acknowledge the immense struggles their parents have faced. Thus, transgenerational trauma is not always debilitating or regressive. Instead of suppressing the anger and pain associated with war and genocide, the students in this study learned to work with their families' traumas to create opportunities that addressed the disparities created and perpetuated by state violence and neglect. This work allowed students to engage with their families' traumatic histories while they strived for opportunities that were systematically denied to their parents by war displacement, unequal access to higher education, and a lack of institutional support for refugees.

Beyond filial connections, refugee subjecthood can also act to bring together disparate groups of people. My interviewees noted that whenever they meet other Cambodians, they would immediately feel connected because they share a similar history of struggle and survival. For example, when Chann attended an educational summit, he automatically felt very connected to one of the Cambodian panelists. Chann rarely talks about his precarious immigration status, but he felt completely comfortable with this stranger. When he shared his fears of deportation, the panelist responded with how she had lost a little girl during the KR regime. The woman said that her young daughter would repeat, "Mom, I'm hungry," but there was nothing she could do. Although it was very painful for her to recall those memories, this connection was so important because it was forged through their respective fears and losses. Chann said, "It's a hard way to connect to people but Cambodian people ... I think about the story of my mom." Because Cambodians have a shared history, they can empathize and draw on personal and intergenerational experiences. In the case for Chann, he thought about his mother and her struggles to cope with the loss of her baby brother and other family members.

Even though Chann had just met this panelist, he immediately formed an affective connection to her; they were tethered together by a common experience of loss. Chann had never experienced the KR firsthand, but he empathized because he had heard so many stories from his mother about all the pain and suffering that were endured during that time. It is also important that the panelist parallels her experience about losing her daughter with Chann's fear of deportation. Both experiences are rooted in pain and uncertainty, and both can be traced back to the war. In addition, Chann noted that he is able to more easily connect to his Cambodian peers in college because he says, "When we talk about family, we know how exactly the other person feels or is 
thinking." This embodied connection allows for an intracohort link among children of Cambodian refugees.

\section{Discussion: Cambodian American Subjecthood}

Across this study, very few individuals felt like they fully understood the nuances of their community's past. Beyond individual details interspersed between the here and there, they largely did not know about the sociohistorical and political events that created the contexts in which their elders had to leave everything behind to start new lives as refugees. The coming into recognition about parents' experiences has been critical to individualized identity development. ${ }^{3}$ But when such experiences are based upon commonalties of race, geography, or migration history, a subjecthood is produced. Refugee subjecthood is thus the phenomenon in which refugees collectively and individually create, enact, and challenge the subject positions in which they have been subjected to via social structures such as law and education. As refugee subjects, this study's participants demonstrate the complex and sometimes contradictory ways in which subsequent generation survivors come into recognition of their individual identities and their collective subjecthood around war and diaspora.

This subjecthood also creates linkages that can articulate the common struggles and experiences of Cambodian refugees to that of their children and affiliative groups. The affiliative groups can be other refugees or even other marginalized groups that are subjected to the control of imperial and discriminatory structures (e.g., war, law, and regulation). Unlike identity politics, trauma formation and refugee subjecthood are not based upon a singular politicized identity (i.e., identities based on loss, pain, and wounds) that entrench and inscribe its loss in politics. There must be a recognition of those pains and wounds, but there exists a futurity to trauma that opens up multiple possibilities of engagement. As such, the Cambodian Americans in this study are always coming into recognition about their family's traumatic pasts and working through those histories. They are not necessarily entrenched as wounded subjects that are defined by their parents' state-imposed status: refugees.

As demonstrated by the larger data and discussion in this study, there need not be conscious recognition of one's family's traumatic history for those experiences to yield collective or public feelings. The embodied affective attachments that subsequent generations experience create the condition for trauma to become collective and social in nature. The sense of "what could have been" is so strong among the subsequent generations that it opens the present into the past and allows for an imagining of a different future (one that is not wholly shaped or define by pain and suffering). Sometimes this imagination can create a future that replicates and reproduces various challenges within the community, but other times, as discussed in this article, it can create positive affects that produce a foundation for community engagement and affective bonding. As Elaine Scarry (1985) posited, it is the imagination that allows for us to remake a world that has been destroyed by pain. The potentials to develop such imaginaries, just like the stories of the past, are what create the successive generation refugee subject. Living and navigating that life, within a particular structure of feelings that help situate the conscious and nonconscious affects between kit and kin, are what encompass refugee subjecthood.

Like a racial formation (Omi \& Winant, 1994), a trauma formation (particularly one based upon transgenerational trauma) is socially constructed and contested. The mental health struggles experienced by the first generation can manifest as negative affects in the subsequent generations - but not necessarily so. Most participants have experienced both simultaneously, and 
their identities are constantly being built and rebuilt by these contradictions. Responses to trauma are varied - from the negative to the positive, from the fantastic to the mundane. These polarities, however, can never fully map the complexity of trauma; they nonetheless reveal an intricacy in the ways in which trauma can be conceptualized, understood, and felt: how affects of trauma produce refugee subjects who then negotiate and renegotiate their identities based on their lived and felt experiences with collective trauma.

In both popular media and scholarly studies, Southeast Asian Americans are often perceived as "unsuccessful" because of challenges associated with poverty, low educational attainment, and gang violence. While this argument can help debunk assumptions of the model minority, it also reifies deficiency, substituting one stereotype for another. To increase educational justice and inclusion, higher education practitioners must understand the unique strengths and challenges of subsequent generation Cambodian American student. Without grounding our goals of retention and access in such ways, we fixate on pathology rather than possibility.

\section{Notes}

1. Queer relationality offers an entry point in which we can disrupt and bring together a singular-plural existence in which refugee subjects can be with each other in spite of difference - whether it is generational, experiential, or otherwise (Gopinath, 2018).

2. Transgenerational trauma is conceptualized as a form of latent articulation, in which existing but not yet manifest forms of memory are (re)articulated at certain moments in time to produce a story or feeling that pieces together disparate sources of information (Kwan, in press).

3. Similar to many youth people of color living in the United States, Cambodian American youth must negotiate between cultural expectations and American ideals. Like the Hmong Americans in Pa Der Vang's (2014) study, the participants in this study still identify as Cambodian even though their day-to-day cultural practices and language use have largely privileged American values and English. Despite this acculturation, however, Cambodian Americans are still deeply connected to and affected by the KR genocide and their parents' war and migration experiences.

\section{References}

Bell, P. (2002). Subjectivity and identity: Semiotics as psychological explanation. Social Semiotics, 12(2), 201-217.

Cvetkovich, A. (2003). An archive of feelings: Trauma, sexuality, and lesbian public cultures. Duke University Press.

Flatley, J. (2008). Affective mapping: Melancholia and the politics of modernism. Harvard University Press.

Gopinath, G. (2018). Unruly visions: The aesthetic practices of queer diaspora. Duke University Press.

Kidron, C. A. (2010). Silent legacies of trauma: A comoparative study of Cambodian Canadian and Israeli Holocaust trauma descendant memory work. In N. Argenti \& K. Schramm (Eds.), Remembering violence: Anthropological perspective on intergenerational trauma (pp. 193-228). Berghahn Books. 
Kidron, C. A. (2011). Sensorial memory: Embodied legacies of genocide. In F. E. Mascia-Lees (Ed.), A companion to the anthropology of the body and embodiment (pp. 451-503). WileyBlackwell.

Kidron, C. A. (2012). Alterity and the particular limits of universalism comparing Jewish-Israeli Holocaust and Canadian-Cambodian genocide legacies. Current Anthropology, 53(6), 723 754.

Kwan, Y. (2019). Providing asset-based support for Asian American refugees: Interrogating transgenerational trauma, resistance, and affective capital. New Directions in Higher Education, 186, 37-47.

Kwan, Y. (in press). Time-image episodes and the construction of transgenerational trauma narratives. Journal of Asian American Studies, 23(1), 1-32.

Murphy, K. M. (2019). Mapping memory: Visuality, affect, and the embodied politics in the Americas. Fordham.

Nguyen, V. (2019). Refugeetude: When does a refugee stop being a refugee. Social Text, 32(2), 109-131. doi:doi.org/10.1215/01642472-7371003

Omi, M., \& Winant, H. (1994). Racial formation in the United States: from the 1960s to the 1990s ( $2^{\text {nd }}$ ed.). Routledge.

Scarry, E. (1985). The body in pain: The making and unmaking of the world. Oxford University Press.

Schensul, S. L., Schensul, J. J., \& LeCompte, M. D. (1999). Essential ethnographic methods: Observations, interviews, and questionnaires. Altamira Press.

Um, K. (2015). War, revolution, and the making of the Cambodian diaspora. New York University Press.

Vang, P. D. (2014). Hmong and acculturation. In J. Merton (Ed.), Acculturation: Psychology, processes and global perspective (pp. 115-136). Nova Publishers.

Wajnryb, R. (2001). The silence: How tragedy shapes talk. Allen \& Unwin.

\section{About the Author}

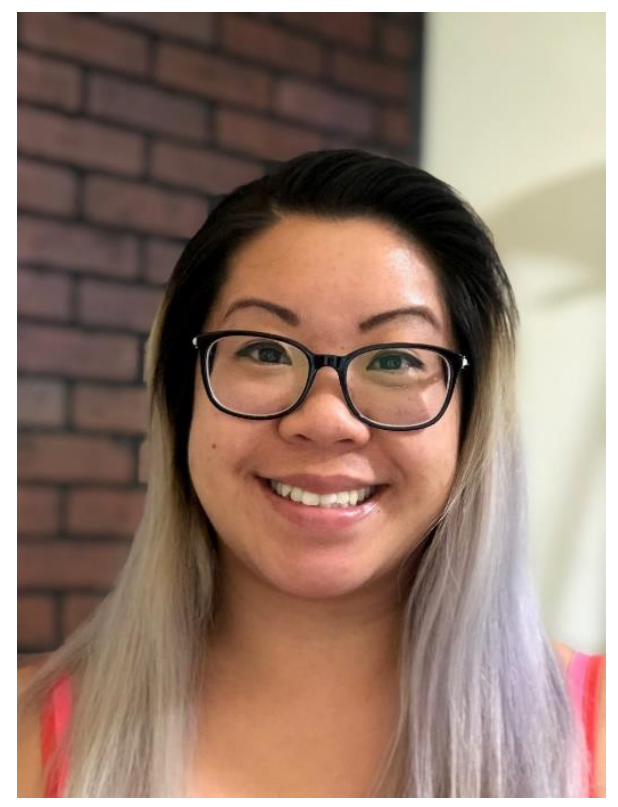

Yvonne Y. Kwan, is an Assistant Professor of Asian American Studies in the Department of Sociology and Interdisciplinary Social Sciences at San Jose State University. As the Director of the Ethnic Studies Collaborative, Kwan has worked closely with campus community partners and other Ethnic Studies faculty in the College of Social Sciences to create a minor in Comparative U.S. Race and Ethnic Relations. Having served as Co-Chair of the Asian Pacific Islander Desi/American Task Force, she has advocated for curricular and co-curricular support for APID/A students. Kwan's research has been published in the Journal of Asian American Studies, New Directions for Higher Education, and the Bilingual Research Journal. Her current book manuscript addresses transgenerational transmission of trauma among Cambodian Americans in California. Kwan was also the convener and lead organizer of the 2020 Southeast Asian American Studies Conference. 

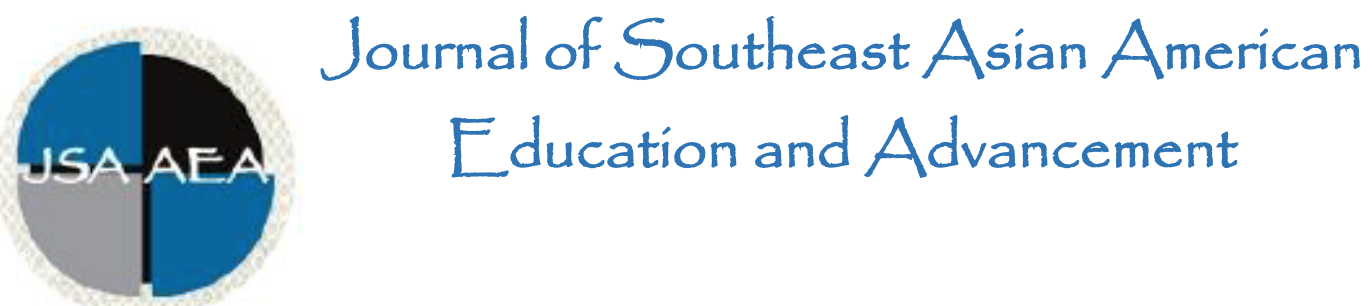

Vol. 15 Iss. 2 Special Issue (2020) $\quad$ www.JSAAEA.org

Special Issue Co-Editors

Dr. Peter T. Keo

Stanford University

Dr. Loan Thi Dao

St. Mary's College of California

\title{
Editor
}

Dr. Wayne E. Wright

Purdue University

Associate Editors

Dr. Chhany Sak-Humphry

University of Hawaii at Manoa

Dr. Phitsamay Sychitkokhong Uy

University of Massachusetts, Lowell

\author{
Book Review Editor \\ Dr. Vichet Chhuon \\ University of Minnesota \\ Creative Works Editor \\ Bryan Thao Worra \\ Lao Assistance Center \\ Journal Manager \\ Fang Gao \\ Purdue University
}

\section{Editorial Review Board}

Dr. Steve Arounsack

California State University, Stanislaus

Dr. Sovicheth Boun

Salem State University
Dr. Carl L. Bankston III

Tulane University

Dr. Phala Chea

Lowell Public Schools 


\author{
Dr. Virak Chan \\ Purdue University \\ Dr. Loan Dao \\ St. Mary's College of California \\ Dr. Changming Duan \\ University of Missouri-Kansas City \\ Dr. Sothy Eng \\ Lehigh University \\ Dr. Vincent K. Her \\ University of Wisconsin, Eau Claire \\ Dr. Peter Nien-Chu Kiang \\ University of Massachusetts, Boston \\ Dr. Kevin K. Kumashiro \\ University of Illinois, Chicago \\ Dr. Ha Lam \\ Independent Scholar \\ Dr. Jonathan H. X. Lee \\ San Francisco State University \\ Dr. Monirith Ly \\ Royal University of Phnom Penh \\ Dr. Bic Ngo \\ University of Minnesota \\ Dr. Leakhena Nou \\ California State University, Long Beach \\ Dr. Mark Pfeifer \\ SUNY Institute of Technology \\ Dr. Loan T. Phan \\ University of New Hampshire \\ Dr. Karen Quintiliani \\ California State University, Long Beach \\ Dr. Angela Reyes \\ Hunter College \\ The City University of New York \\ Dr. Fay Shin \\ California State University, Long Beach \\ Dr. Christine Su \\ College of San Mateo \\ Dr. Alisia Tran \\ Arizona State University \\ Dr. Khatharya Um \\ University of California, Berkeley \\ Dr. Kim Tran \\ University of California, Los Angeles, \\ Glendale Community College \\ Dr. Molly Wiebie \\ The University of Texas at Austin
}

Dr. George Chigas

University of Massachusetts, Lowell

Dr. Hien Duc Do

San Jose State University

Dr. Sophal Ear

Occidental College

Dr. Jeremy Hein

University of Wisconsin, Eau Claire

Dr. Nancy H. Hornberger

University of Pennsylvania

Dr. Peter Tan Keo

Stanford University

Dr. Yvonne Kwan

San Jose State University

Dr. Ravy Lao

California State University, Los Angeles

Dr. Stacey Lee

University of Wisconsin, Madison

Dr. Sue Needham

California State University, Dominguez Hills

Dr. Max Niedzwiecki

Daylight Consulting Group

Dr. Clara Park

California State University, Northridge

Dr. Giang Pham

University of Massachusetts Amherst

Dr. Malaphone Phommasa

University of Clifornia Santa Barbara

Dr. Kalyani Rai

University of Wisconsin-Milwaukee

Dr. Cathy J. Schlund-Vials

University of Connecticut, Storrs

Dr. Nancy J. Smith-Hefner

Boston University

Dr. Yer J. Thao

Portland State University

Dr. Monica M. Trieu

Purdue University

Dr. Silvy Un

Saint Paul Public Schools

Dr. Linda Trinh Vo

University of California, Irvine

Dr. Yang Sao Xiong

The University of Wisconsin-Madison

Dr. Zha Blong Xiong

University of Minnesota 


\section{Doctoral Student Editorial Review Board}

\author{
Diana Chandara \\ University of Minnesota-TwinCiteis \\ Linh Dang \\ University of Rochester \\ Annie BichLoan Duong \\ San Joaquin County Office of Education \\ Jacqueline Mac \\ Indiana University \\ Vanessa Sovanika Na \\ University of California SanDiego \\ Khoi Nguyen \\ George Mason University \\ Linda Marie Pheng \\ University of Wisconsin-Madison \\ Latana Thaviseth \\ University of California Los Angeles \\ Melissa Vang \\ San Diego State University \\ Soua Xiong \\ San Diego State University \\ Claremont Graduate University
}

\author{
Kassandra Chhay \\ University of Minnesota-Twin Cities \\ Bao Diep \\ University of Minnesota-Twin Cities \\ Nielson Hul \\ Cornell University \\ Dung Minh Mao \\ University of Minnesota-Twin Cities \\ Hoa Nha Nguyen \\ Boston College \\ Thien-Huong Ninh \\ University of Southern California \\ Krissyvan Truong \\ Claremont Graduate University \\ Mai Vang \\ University of Massachusetts Boston \\ Thong Vang \\ University of Minnesota-Twin Cities
}

